\title{
ANURANS FROM A LOCAL ASSEMBLAGE IN CENTRAL BRAZIL: LINKING LOCAL PROCESSES WITH MACROECOLOGICAL PATTERNS
}

\author{
DINIZ-FILHO, J. A. F., ${ }^{1}$ BINI, L. M., ${ }^{1}$ BASTOS, R. P., ${ }^{2}$ VIEIRA, C. M., ${ }^{3}$ SOUZA, M. C., ${ }^{4}$ \\ MOTTA, J. A. O., ${ }^{5}$ POMBAL, J. P. Jr. ${ }^{6}$ and PEIXOTO, J. C. ${ }^{4}$ \\ ${ }^{1}$ Laboratório de Ecologia Teórica e Síntese, Departamento de Biologia Geral, Instituto de Ciências Biológicas, \\ Universidade Federal de Goiás, CEP 74001-970, Goiânia, GO, Brazil \\ ${ }^{2}$ Departamento de Biologia, Instituto de Ciências Biológicas, Universidade Federal de Goiás, \\ CEP 74001-970, Goiânia, GO, Brazil \\ ${ }^{3}$ Laboratório de Biodiversidade do Cerrado, Departamento de Biologia, Universidade Estadual de Goiás, \\ Av. Juscelino Kubitschek, 146, Bairro Jundiaí, CEP 75110-390, Anápolis, GO, Brazil \\ ${ }^{4}$ Programa de Pós-Graduação em Biologia, Instituto de Ciências Biológicas, Universidade Federal de Goiás, \\ CEP 74001-970, Goiânia, GO, Brazil \\ ${ }^{5}$ IBAMA, GO \\ ${ }^{6}$ Departamento de Vertebrados, Museu Nacional, Universidade Federal do Rio de Janeiro, \\ CEP 20940-040, Rio de Janeiro, RJ, Brazil \\ Correspondence to: José Alexandre F. Diniz-Filho, Laboratório de Ecologia Teórica e Síntese, Departamento de \\ Biologia Geral, Instituto de Ciências Biológicas, Universidade Federal de Goiás, CEP 74001-970, \\ Goiânia, GO, Brazil, e-mail: diniz@icb1.ufg.br \\ Received August 19, 2002 - Accepted January 24, 2003 - Distributed February 29, 2004
}

(With 4 figures)

\begin{abstract}
Macroecological variables of Anuran species found in a local assemblage from Central Brazil (Silvânia, Goiás State) were linked to population dynamics statistics of these species. Geographical range size (GRS), body size, and species' midpoints were the macroecological variables investigated for those species found in the local assemblage and for all other species (105 in the total) found in the Cerrado biome. For each species found in the local assemblage, data on abundance was obtained. Using this data, local population variability as expressed by the coefficient of variation was estimated. Distribution of means, medians, maximum, variances, and skewness (g1), for both GRS and body size, estimated in the local assemblage were compared, using null models, with the data extracted from the overall Cerrado species pool. The results indicated a clear macroecological relationship between GRS and body size and a decrease in local abundance when distance between the locality analyzed and species midpoint increased. According to null models, both body size and GRS values measured in the local assemblage can be considered a random sample from the regional species pool (Cerrado region). Finally, a three-dimensional analysis using body size, GRS, and local population estimates (abundance and variability), indicated that less abundant and more fluctuating species fell near the lower boundary of the polygonal relationship between GRS and body size. Thus, macroecological results linked with local data on population dynamics supported the minimum viable population model.
\end{abstract}

Key words: Anura, macroecology, population abundance, Cerrado.

\section{RESUMO}

\section{Anuros de uma assembléia local do Brasil Central: relacionando processos locais a padrões macroecológicos}

Variáveis macroecológicas de uma assembléia local de espécies de anfíbios anuros do Brasil Central (Silvânia, Estado de Goiás) foram relacionadas com estatísticas de dinâmica de população dessas espécies. A extensão 
de ocorrência (GRS), o tamanho de corpo e o centro de distribuição das espécies foram as variáveis macroecológicas investigadas para as espécies da assembléia local e para todas as outras espécies (105 no total) encontradas no bioma de Cerrado. Também foram obtidos dados de abundância para 15 espécies da assembléia local. Usando esses dados, a variabilidade populacional foi estimada pelo coeficiente de variação. A distribuição de médias, medianas, máximos, assimetrias e curtoses, para GRS e tamanho de corpo, da assembléia local foi comparada, por intermédio de modelos nulos, com os dados do conjunto de espécies do Cerrado. Os resultados indicaram clara relação macroecológica entre a GRS e o tamanho do corpo, bem como diminuição da abundância local com o aumento da distância entre os centros de distribuição das espécies e a localidade analisada. De acordo com os modelos nulos, os valores do tamanho de corpo e da GRS das espécies da assembléia local podem ser considerados uma amostra aleatória proveniente da composição regional de todo o Cerrado. Finalmente, uma análise tridimensional considerando o tamanho do corpo, a GRS, a abundância local e a variabilidade populacional indicou que espécies menos abundantes, com maior variabilidade populacional, estão próximas ao limite inferior da relação poligonal entre GRS e tamanho de corpo. Assim, os resultados macroecológicos, quando relacionados a dados obtidos em pequenas escalas espaciais, corroboraram o modelo de população mínima viável.

Palavras-chave: Anura, macroecologia, abundância, Cerrado.

\section{INTRODUCTION}

Macroecology evaluates the relationship among complex ecological variables (usually body size, geographical range size, and population density) measured for multiple species on a continental scale (Brown, 1995; Maurer, 1999; Gaston \& Blackburn, 2000; Blackburn \& Gaston, 2001). In recent years, a considerable increase in macroecology research programs has occurred worldwide, addressing many questions about patterns and processes related to statistical distributions (Blackburn \& Gaston, 1994a, b), relationships among macroecological variables (Gaston \& Blackburn, 1996), and their spatial and phylogenetic patterns (Brown, 1999; Duncan et al., 1999; Gaston \& Blackburn, 1999, 2000; Cardillo, 2002).

However, as Blackburn \& Gaston (1998) and Gaston \& Blackburn (1999) recently pointed out, one of the main criticisms of macroecology research programs is that they do not yet include a substantial body of mathematical modeling and an associated unifying theoretical framework. Moreover, Brown (1999) also points out that major emphasis in macroecological analyses has been in the establishment of patterns, but not in discovering underlying ecological and evolutionary processes.

These criticisms are linked to the common problem of inferring ecological processes from largescale patterns (Ricklefs \& Schluter, 1993; Levin, 1992). Thus, it is necessary to go down in the ecological hierarchy to a local spatial scale, which is the relevant one for natural assemblages. Subsequently, specific processes acting on local assemblages can be invoked to explain large-scale patterns (Cyr et al., 1997). A well known example is the relationship between local population density and body size, that is usually linked to the energetic processes in local communities by the so-called "energetic equivalence rule" (EER) (Damuth, 1981; Blackburn \& Gaston, 1997a, b, 1999). Despite many recent criticisms of EER (Bini et al., 2001 and references therein), it is nevertheless a good example of how a large-scale trend can be understood based on theory and models previously developed to be applied in a lower hierarchical level (Cyr et al., 1997).

The purpose of this paper is to evaluate how macroecological patterns in a local assemblage of Anura from Central Brazil (Silvânia, Goiás State) can be linked to local population dynamics. Despite the relatively low number of species, data on population dynamics among them are available, permitting, through extrapolation of inferred processes, the explanation of macroecological patterns.

\section{MATERIAL AND METHODS}

From June 1995 to May 1998, monthly, surveys were made in a tropical $(1,600 \mathrm{~mm}$ annual rainfall) Brazilian national forest conservation unit in Goiás State (Silvânia Municipality; 16³9'S, 
$\left.48^{\circ} 36^{\prime} \mathrm{W}\right)$. The protected area (900 MSL) occupies approximately 466 ha, and presents typical cerrado physiognomies: Cerrado (sensu stricto), cerradão, campo cerrado, and riparian forest (Oliveira-Fillho \& Ratter, 2002).

In each survey, anurans were registered by visual encounter survey (Crump \& Scott Jr., 1994) and by audio strip transect (Zimmerman, 1994). Abundance data of 15 out of the 26 species found in Silvânia that were also included in the macroecological analyses (see below) were obtained by using this sampling procedure (Table 1). Based on an extensive literature review and on records of the Museu Nacional (Universidade Federal do Rio de Janeiro), macroecological data was collected for a pool of 105 species found in the Cerrado area of Central Brazil (Appendix 1; see also Colli et al., 2002). Species whose taxonomic status was undefined or that probably belong to groups of species (i.e., Scinax gr. ruber or Bufo gr. granulosus) were excluded from our macroecological data set. For each species, GRS (extent of occurrence) was defined by a minimum convex polygon based on occurrence points (Gaston, 1994). Based on this, we defined the geographical distance from Silvânia, where the local assemblage was monitored, to the species midpoint, determining in this way if the population in this local assemblage, for a given species, is a central or peripheral population (Channell \& Lomolino, 2000). Body size was considered as the average snout-vent length (SVL) obtained in the literature and expressed in millimeters. Thus, when comparing the fauna of Silvânia with that of the Cerrado overall, 15 species were included when using population dynamics data, and 26 species were used when dealing with macroecological (SVL and GRS) data only.

\section{Data analysis}

A first-order autoregressive model was fitted to estimate the degree of temporal autocorrelation of each time series (abundance data for each of the 15 species). The following model was used:

$$
x_{t}=\phi_{1} x_{t-1}+e_{t}
$$

where $x_{t}$ is the abundance (in logarithmic scale plus 1.0) estimate for month $t, \phi_{1}$ is the autoregressive parameter, and $e$ is the random error component. Each observation is made up of a random error component and a linear combination (if more than one autoregressive parameter is fitted) of prior observations.

\section{TABLE 1}

Fifteen species found in Silvânia (Goiás State) and the macroecological data used in this study. Abbreviations: SVL = snout vent length $(\mathrm{mm})$; GRS = geographic range size $\left(\mathrm{km}^{2}\right)$; DIST = distance from midpoint to Silvânia in $(\mathrm{km})$; LPA = mean local population abundance (number of individuals-log scale).

\begin{tabular}{|l|c|c|c|c|}
\hline \multicolumn{1}{|c|}{ Species } & SVL & GRS & DIST & LPA \\
\hline Bufo schneideri & 150.0 & 2753669 & 65 & 0.116 \\
\hline Bufo rubescens & 107.5 & 937612 & 364 & 0.058 \\
\hline Hyla albopunctata & 55.1 & 1942199 & 260 & 1.641 \\
\hline Hyla biobeba & 52.2 & 558866 & 195 & 1.814 \\
\hline Hyla cruzi & 11.5 & 215272 & 52 & 1.205 \\
\hline Hyla goiana & 33.1 & 392925 & 65 & 1.881 \\
\hline Hyla minuta & 22.6 & 6201303 & 117 & 0.1 \\
\hline Hyla pseudopseudis & 41.2 & 337865 & 78 & 0.019 \\
\hline Leptodactylus labyrinthicus & 130.1 & 4011249 & 299 & 0.05 \\
\hline Leptodactylus ocellatus & 103.0 & 3337023 & 0 & 0.039 \\
\hline Odontophrynus cultripes & 57.0 & 2385638 & 559 & 0.196 \\
\hline Phyllomedusa hypochondrialis & 33.5 & 1990972 & 715 & 0.108 \\
\hline Physalaemus cuvieri & 28.0 & 3102080 & 130 & 1.007 \\
\hline Scinax centralis & 25.0 & 33800 & 0 & 0.171 \\
\hline Scinax fuscomarginatus & 24.0 & 1649474 & 247 & 0.031 \\
\hline
\end{tabular}


For each species, we calculated the mean value of $x_{t}$ and used it as a measure of local abundance. Variability of the $x_{t}$ values was characterized by their coefficient of variation (McArdle et al., 1990). We then correlated these local estimates (mean, coefficient of variation, and autoregressive coefficient) with large-scale macroecological data established across species.

The shape of the relationship between geographical range size and SVL was defined as a left triangle, with a symmetrical and upper right boundary. The null hypothesis of no relationship between GRS and SVL (i.e., the selected shape can be obtained by chance alone) was assessed by randomization procedures implemented in EcoSim v. 7.0 (Gotelli \& Entsminger, 2000). Two criteria were used. First, the dispersion index (i.e., variance), which was calculated by dividing the bivariate space into four quadrants based on location of species points (median of the two variables), was compared with the distribution of variances obtained after randomizing the species positions in the bivariate space. The distribution was created by 1,000 simulated data sets. Thus, this procedure detects only nonrandom aggregation of species in the bivariate space formed by GRS and SVL. Second, a polygonal shape, as defined above and using the default options of EcoSim for the selection of the shape, was imposed on the data and the number of species falling within the envelope was counted. This value was then compared with a null distribution of point counts constructed by randomizing 1.000 times the species position in the bivariate space. If the species are unusually clustered within the shape, then the observed number of species will be significantly larger than the number found in most randomized data sets.

The GRS/SVL relationship was also analyzed using the 26 species found in Silvânia only, and compared with the same relationship based on the 105 species in the Cerrado species pool.

\section{Species assembly rules assessment}

We randomly drew 26 species from the Cerrado species pool $(n=105)$, matching then with the species richness in Silvânia, and repeated this procedure 1,000 times, comparing the distribution of means, medians, maximum, variances, and skewness (g1) (Sokal \& Rohlf, 1995), for both GRS and SVL, with real values defined for the local assemblage from Silvânia (Blackburn \& Gaston, 2001).
These estimates were expected to describe the statistical distribution of these two variables, which is usually extremely asymmetric (Gaston \& Blackburn, 2000). Thus, it would be possible to determine if the GRS and SVL of those species found in the local assemblage (Silvânia) is a typical assemblage randomly extracted from the overall Cerrado species pool.

\section{RESULTS}

Despite the relatively low number of species and consequent difficulties in testing relationships by standard regression approaches or definition of constraint envelopes (due to low statistical power), some relationships between local statistics and macroecological variation followed overall expected tendencies (Fig. 1). There was a decrease in abundance when distances between Silvânia and species midpoint increases, but there was not a positive relationship between local population abundance and geographical range size, as expected (Fig. 1A, B). There was also a negative relationship between auto-regressive coefficient and body size (Fig. 1C) and between local population abundance and body size (Fig. 1D). As indicated above, these are only general tendencies with interpretable upper boundaries (see Discussion).

The frequency distributions of SVL and geographical range sizes from both Silvânia and Cerrado species pool were right-skewed (Fig. 2), as expected by considering patterns in other macroecological data (Blackburn \& Gaston, 2001, and references therein). More importantly, for the two variables, means, medians, variances, maximums, and $\mathrm{g}_{1}$, estimated in the local assemblage can be considered random values extracted from the Cerrado species pool (Table 2) (with a single exception, i.e., variance in body size, with a $P$-value of 0.03 ).

Considering the 105 species pool, there is a clear triangular relationship between GRS and SVL (Fig. 3), that is significant at $\mathrm{p}=0.039$ by the randomization procedures in EcoSim using the dispersion index. This indicates that there is a significant concentration of species in one of the corners of the bivariate space. Also, there is a significant fit of the triangular constraint envelope, since the number of species falling within the limits of this polygon is also significantly larger than that observed by chance alone $(\mathrm{p}=0.047)$. 

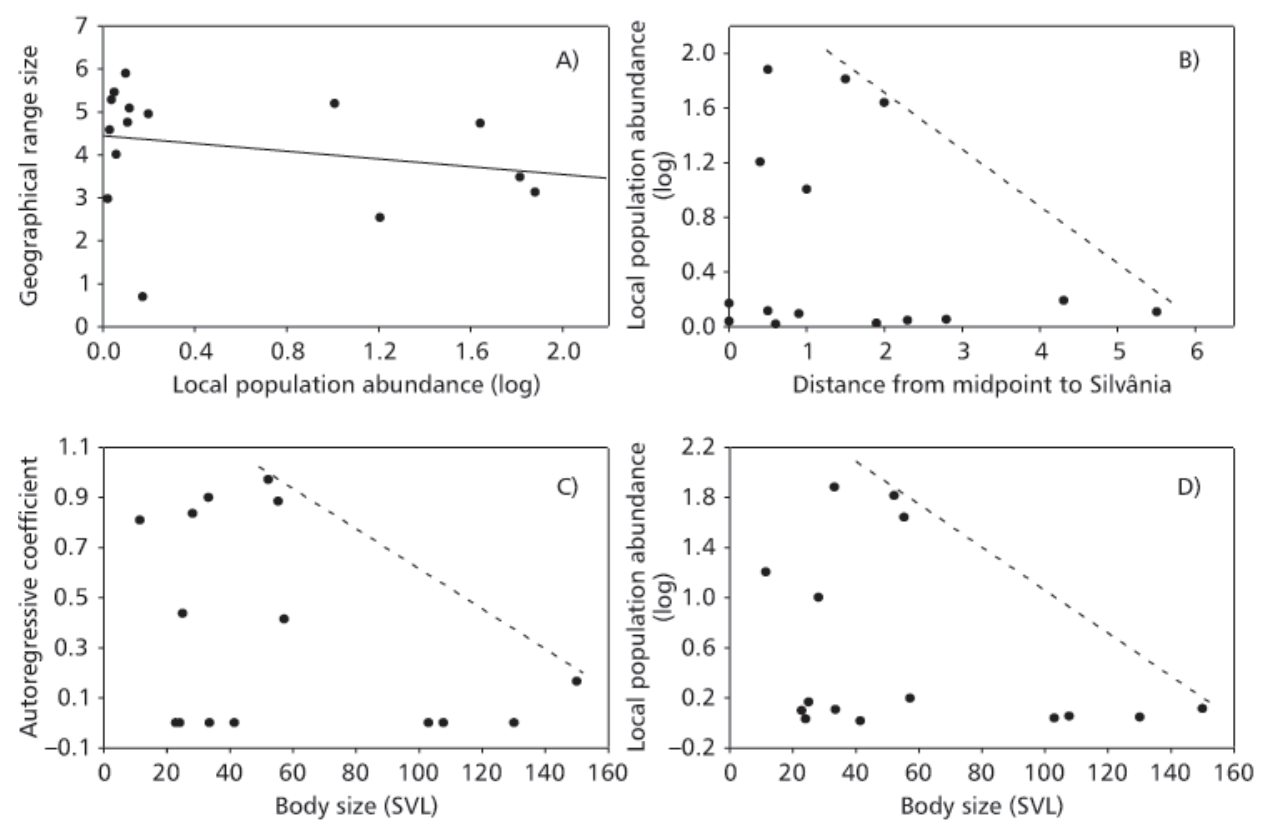

Fig. 1 - Relationships between (A) GRS and local population abundance (LPA), (B) LPA and distance from midpoint to Silvânia (where the local assemblage was studied), (C) body size (snout-vent length; SVL) and the autoregressive coefficient, and (D) and SVL and LPA.

When the relationship is tested using the Silvânia species, the overall triangular shape remains, with a large overlap between the two polygons (Fig. 3). However, the statistical tests of dispersion and species count are no longer significant. Considering the small number of species in the local assemblage studied, this result can be attributed to low statistical power. However, as indicated above, the relationship was similar to that detected with the large-scale data.

We performed a contouring procedure on both local population abundance and population variability (as expressed by the coefficient of variation of local abundance), using the distance weighted least squares procedure (DWLS), over the bivariate space formed by GRS and SVL (Fig. 4). Thus, contour regions indicate the third variable analyzed (GRS, SVL, and population abundance in Fig. 4A, and geographical range size, SVL, and population variability in Fig. 4B). It is possible to note that less abundant and more fluctuating species fall exactly within the lower boundary, with a gra- dient of increasing abundance and decreasing fluctuation toward the central region of the polygon.

\section{DISCUSSION}

The links between local processes of community or population dynamics and macroecological patterns are not easily established, by reason of difficulties in sampling and variable definition (Blackburn \& Gaston, 2001). In our study of anurans from Silvânia, the main problem is that the number of species analyzed at the local scale by population dynamics variables (abundance and variability) is only a relatively small part of the Cerrado species pool for which macroecological patterns can be established.

Thus, the detection of expected relationships is constrained due to data paucity, noise, scaling effects, complexity, and non-linearity of the relationships. Despite the low statistical power, few interesting and interpretable patterns appeared in our relatively small data set. 


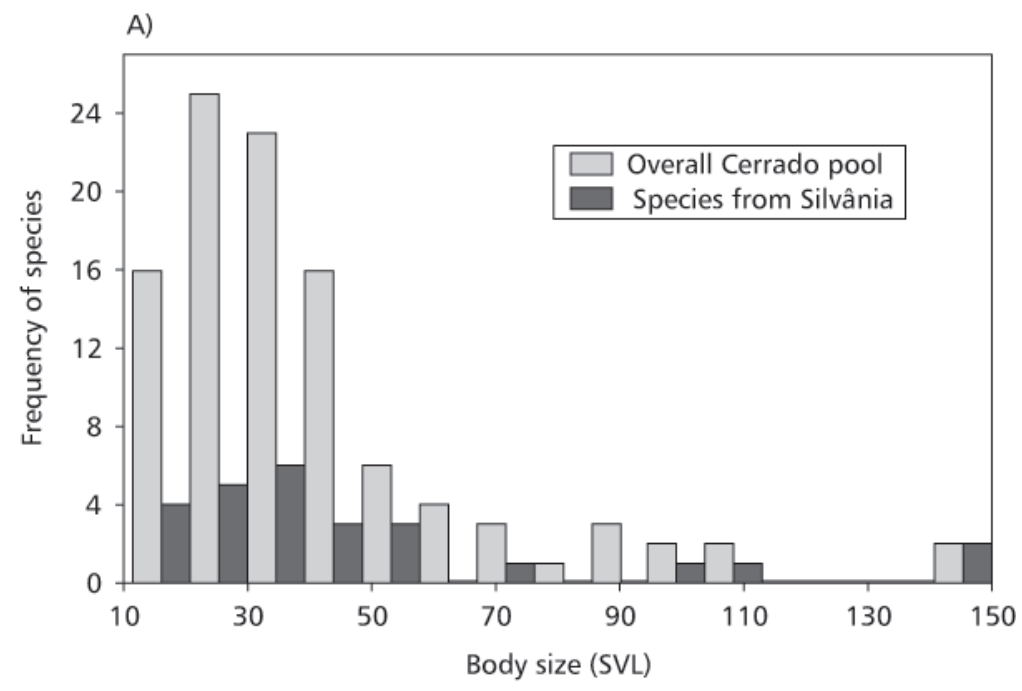

B)

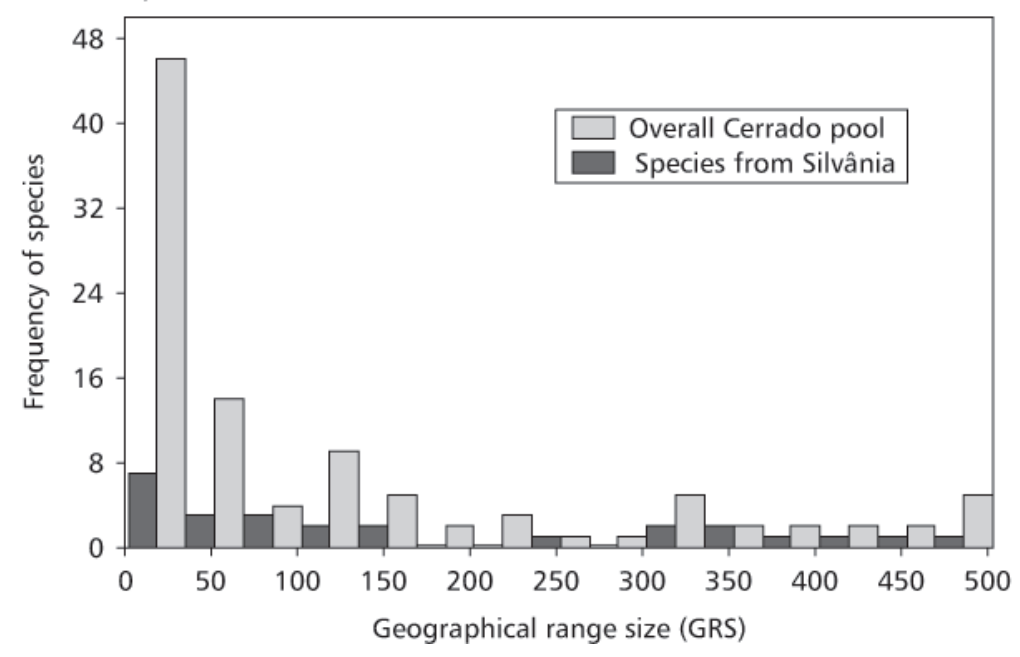

Fig. 2 - Frequency distributions of species SVL (A) and GRS (B), from both Silvânia and Cerrado species pool.

Using body size expressed by SVL as a predictor, it is possible to see that both mean population abundance and autoregressive coefficients tend to be smaller for species with larger body size.

Thus, larger species are less abundant and have low auto-regressive coefficients (less predictable or with less variation in abundance) when compared to smaller species. A negative relationship between population abundance and body size can be explained by mass-related energy requirements (Carbone \& Gittleman, 2002, and references therein).
The different forms of the interspecific relationship between abundance and body size in animals (a simple monotonic relationship or a nonhomogeneous polygonal relationships), however, may be a product of different sampling scales (Lawton, 1989; Blackburn \& Gaston, 1997a). High temporal autocorrelation may indicate population stability, which tends to be higher in large-bodied species. In this way, the negative relationship between abundance and temporal autocorrelation is hard to explain. 
TABLE 2

Basic statistics (mean, median, variance, maximum, and skewness) for body size (SVL) and geographical range size (GRS) of the species found in the Cerrado species pool $(n=105)$ and in Silvânia $(n=26)$. The probability that these statistics estimated for Silvânia species differ from randomly selected species from the Cerrado pool with $n=26$ is given by p (pool).

\begin{tabular}{|l|c|c|c|c|c|c|}
\hline & \multicolumn{3}{|c|}{ SVL } & \multicolumn{3}{c|}{ GRS } \\
\hline & Cerrado & Silvânia & p (pool) & Cerrado & Silvânia & p (pool) \\
\hline Mean & 41.09 & 47.88 & 0.111 & 119.84 & 170.61 & 0.059 \\
\hline Median & 32.58 & 34.07 & 0.386 & 45.00 & 100.50 & 0.087 \\
\hline Variance & 700.41 & 1420.57 & 0.030 & 23721.08 & 27371.53 & 0.328 \\
\hline Maximum & 150.00 & 150.00 & 0.233 & 576.00 & 503.00 & 0.503 \\
\hline g1 & 1.98 & 1.64 & 0.456 & 1.45 & 0.676 & 0.676 \\
\hline
\end{tabular}

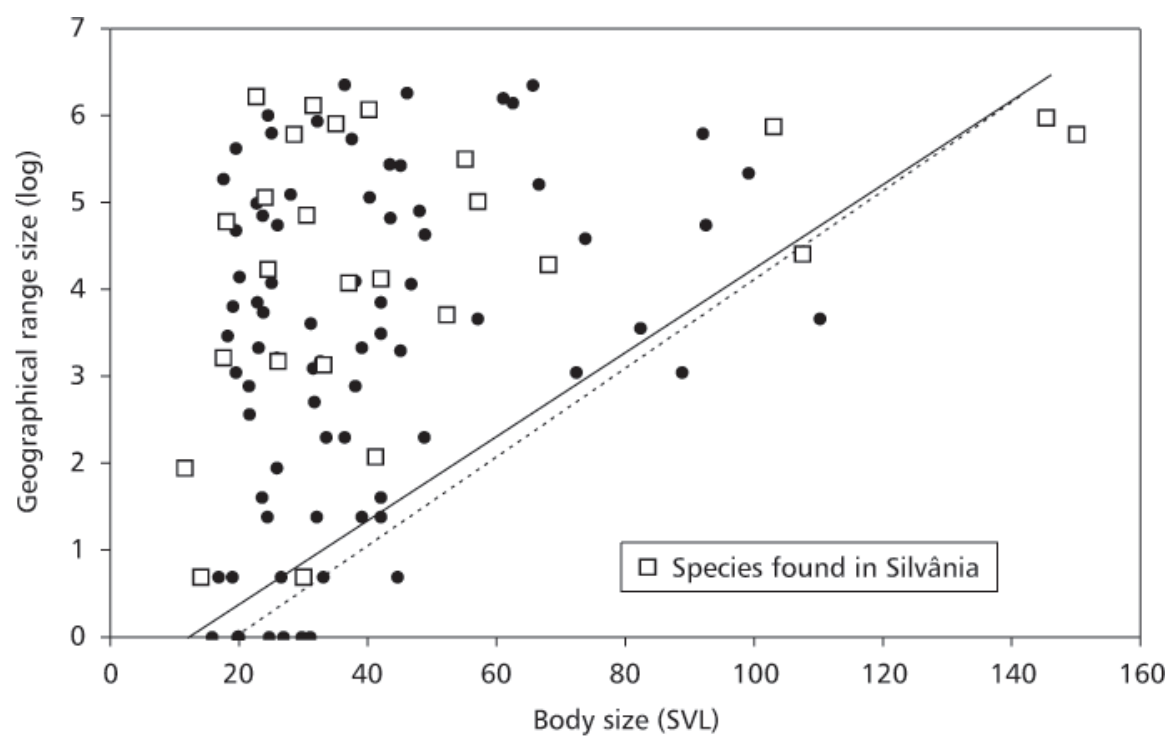

Fig. 3 - Relationship between GRS and SVL. The boundaries were fitted according to Gotelli \& Entsmiger (2000). Dashed line $=$ overall data; continuous line $=$ Silvânia data.

Besides, the coefficient of variation does not show a clear tendency, indicating that magnitude of population variability is not related to other variables, at least at this scale. Mean population abundance also decreases with increasing distance from species midpoint to Silvânia, indicating that local populations in the periphery of the distri- bution, tend to be less dense (Brown et al., 1995; Blamires et al., 2002). Thus, local abundance is both a function of attributes (such as body size) and of the demographic and adaptive parameters (i.e., growth rate) that may be associated with local environment in terms of distance to the optimum of the species (Maurer, 1994). 


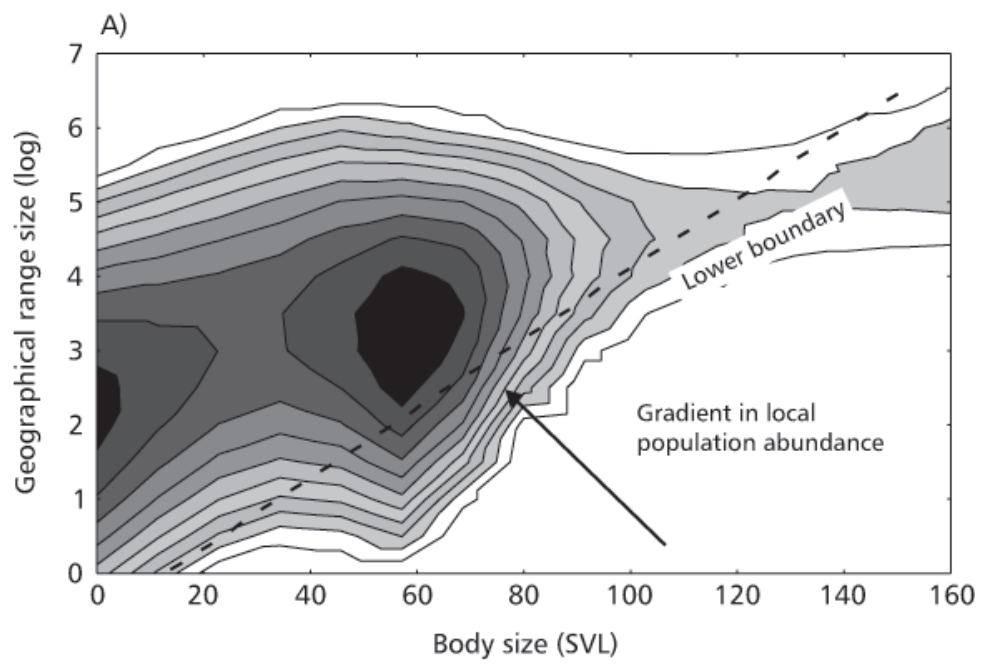

B)

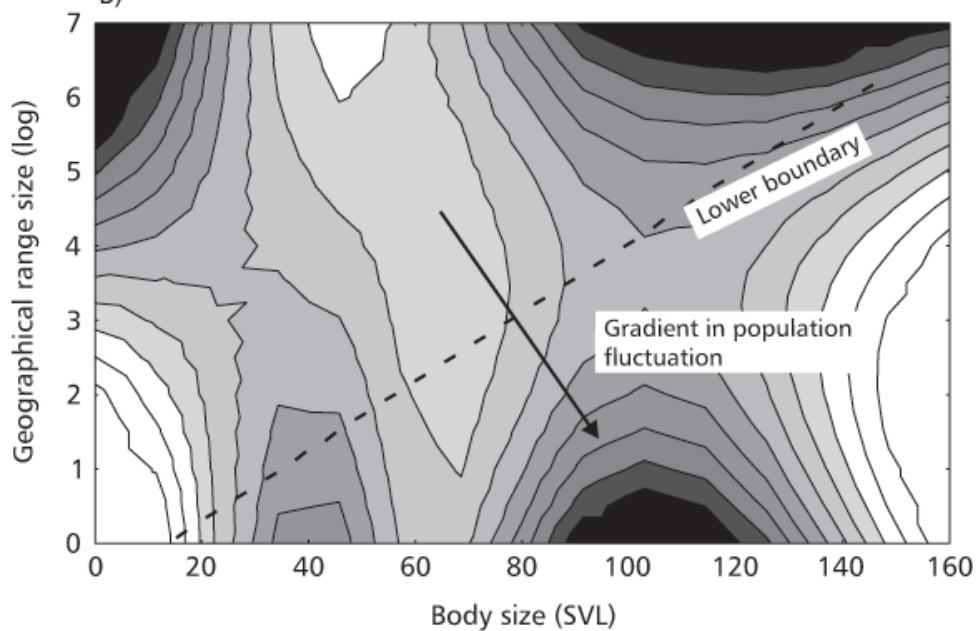

Fig. 4 - Distance weighted least squares procedure smoothing fitted over the bivariate space formed by GRS and SVL. Contours in (A) are based on mean abundance data and contours in (B) are based on temporal coefficient of variation of population abundance. The arrows indicate the tendencies of increase in these variables.

Resampling procedures indicate that both SVL and GRS values measured in the local assemblage studied can be characterized as a random sample coming from the regional species pool (Cerrado region). This result can be explained by the central position of Silvânia within the Cerrado region, both geographically and in terms of habitat representation occurring at a more regional scale. Also, the significant polygonal relationship between GRS and SVL is similar to those in other groups of species (Brown \& Maurer, 1989; Brown, 1995) and more clear than those found for anurans in other parts of the world (Murray et al., 1998). For Silvânia species only, the pattern is quite similar. But the most important aspect to note is how less abundant and more fluctuating species overlap on this bivariate space, a consistent pattern for which would support the minimum viable population model explaining the relationship between body size and geographical range size (Brown \& Maurer, 1987, 1989; Gaston $\&$ Blackburn, 1996). Indeed, less abundant and more fluctuating species fall near the lower boundary, with a gradient toward the central region of the polygon. 
This pattern is consistent with the minimum viable population model, in which the lower boundary is a probabilistic constraint line linked to a stochastic extinction process. In general, largerbodied species require larger range sizes in order to maintain minimum viable populations (Brown \& Maurer, 1987). Differential extinction of species of large body size with low population abundance prevents the occurrence of numerous widely distributed large-bodied species in the regional pool. In addition, species of large body size tend to have extensive geographical ranges. As indicated by Figs. 3 and 4, a species is unlikely to occur with the following characteristics combined: low population abundance, large body sizes, low geographical range size, and higher population variability. The slope of the lower boundary would be largely variable among different groups of organisms and dependent on many factors, including extinction rates, dependence of population dynamics on body mass, and intensity of local competition. Although the number of species analyzed is small, predictions are in agreement with minimum viable population model, both in terms of local abundance and po- pulation variability, another variable that has been linked to high extinction probability.

Murray et al. (1998) in analyzing macroecological patterns in Australian frogs rejected Brown's minimum viable population model because partial relationships between body size and geographical range size, after taking into account population density, are still significant. This suggests that this relationship is not fully explained by underlying variations in species density. The preceding authors found out that Gaston's (1991) homeostasis model better explains this relationship. However, it is important to note that relationships among these macroecological variables in not well described by linear models, and partial correlation may be flawed. We believe that observing the overlay between the three variables, as performed here, provides a better approach for understanding more complex non-linear patterns. Although no statistical test on this overlay was performed (and, in fact, it would be useless due to low statistical power), we believe that observed macroecological patterns, linked with data of local population dynamics, support the minimum viable population model.

APPENDIX 1

Species used for macroecological analysis of Anurans from Cerrado region, including their snout-vent length (SVL) and extent of occurrence (geographic range size - GRS), expressed in number of quadrants of $130 \mathrm{~km}$ of side.

\begin{tabular}{|l|c|c|}
\hline \multicolumn{1}{|c|}{ Species } & SVL & GRS \\
\hline Adenomera bokermanni & 23.70 & 42.00 \\
\hline Adenomera hylaedactyla & 24.45 & 405.00 \\
\hline Adenomera martinezi & 24.45 & 69.00 \\
\hline Aplastodiscus perviridis $*$ & 68.00 & 73.00 \\
\hline Barycholos ternetzi ${ }^{*}$ & 26.00 & 24.00 \\
\hline Bufo guttatus & 99.14 & 208.00 \\
\hline Bufo ocellatus & 43.42 & 124.00 \\
\hline Bufo ornatus & 72.35 & 21.00 \\
\hline Bufo rubescens ${ }^{*}, \#$ & 107.50 & 82.00 \\
\hline Bufo schneideri* ${ }^{*}$ \# & 150.00 & 325.00 \\
\hline Chiasmocleis albopunctata $*$ & 30.40 & 129.00 \\
\hline Chiasmocleis centralis & 23.60 & 128.00 \\
\hline Colostethus goianus & 16.75 & 2.00 \\
\hline Crossodactylus bokermanni & 25.80 & 7.00 \\
\hline Dermatonotus muelleri & 66.50 & 183.00 \\
\hline
\end{tabular}


APPENDIX 1 (Continued.)

\begin{tabular}{|c|c|c|}
\hline Species & SVL & GRS \\
\hline Elachistocleis ovalis & 25.00 & 59.00 \\
\hline Eleutherodactylus crepitans & 31.00 & 1.00 \\
\hline Eleutherodactylus duendeei & 29.75 & 1.00 \\
\hline Eleutherodactylus heterodactylum & 24.60 & 1.00 \\
\hline Eleutherodactylus juipoca* & 17.50 & 25.00 \\
\hline Epipedobates braccatus & 20.05 & 63.00 \\
\hline Epipedobates flavopictus & 25.90 & 115.00 \\
\hline Epipedobates pictus & 22.70 & 147.00 \\
\hline Hyla albopunctata* \# & 55.12 & 245.00 \\
\hline Hyla alvarengai & 88.75 & 21.00 \\
\hline Hyla anataliasiasi & 23.00 & 28.00 \\
\hline Hyla araguaya & 19.80 & 1.00 \\
\hline Hyla biobeba*,\# & 52.20 & 41.00 \\
\hline Hyla cerradensis & 18.90 & 2.00 \\
\hline Hyla cipoensis & 31.45 & 22.00 \\
\hline Hyla circumdata & 57.04 & 39.00 \\
\hline Hyla crepitans & 62.50 & 468.00 \\
\hline Hyla cruzi* \# & 11.50 & 7.00 \\
\hline Hyla elianeae & 22.80 & 47.00 \\
\hline Hyla ericae & 26.5 & 2.00 \\
\hline Hyla faber & 92.50 & 115.00 \\
\hline Hyla goiana*, \# & 33.14 & 23.00 \\
\hline Hyla ibitiguara & 42.00 & 4.00 \\
\hline Hyla jimi & 21.60 & 13.00 \\
\hline Hyla melanargyrea & 19.50 & 108.00 \\
\hline Hyla minuta*, \# & 22.62 & 503.00 \\
\hline Hyla multifasciata & 40.20 & 158.00 \\
\hline Hyla nana & 19.50 & 277.00 \\
\hline Hyla nanuzae & 42.00 & 5.00 \\
\hline Hyla pinima & 19.50 & 21.00 \\
\hline Hyla pseudopseudis $*$ \# & 41.20 & 8.00 \\
\hline Hyla punctata & 32.10 & 378.00 \\
\hline Hyla raniceps & 65.64 & 574.00 \\
\hline Hyla rubicundula* & 18.00 & 119.00 \\
\hline Hyla saxicola & 48.75 & 10.00 \\
\hline Hyla sazimai & 36.40 & 10.00 \\
\hline Hyla soaresi $*$ & 31.10 & 37.00 \\
\hline Hyla tritaeniata & 19.00 & 45.00 \\
\hline Hylodes otavioi & 33.50 & 10.00 \\
\hline Leptodactylus curicularius & 38.00 & 18.00 \\
\hline Leptodactylus camaquara & 39.00 & 4.00 \\
\hline Leptodactylus chaquensis & 46.70 & 58.00 \\
\hline Leptodactylus furnarius & 39.00 & 28.00 \\
\hline Leptodactylus fuscus* & 40.10 & 433.00 \\
\hline Leptodactylus jolyi & 45.00 & 27.00 \\
\hline Leptodactylus labyrinthicus ${ }^{*}$ \# & 145.35 & 394.00 \\
\hline
\end{tabular}


APPENDIX 1 (Continued.)

\begin{tabular}{|c|c|c|}
\hline Species & SVL & GRS \\
\hline Leptodactylus mystaceus & 46.02 & 525.00 \\
\hline Leptodactylus mystacinus & 48.02 & 135.00 \\
\hline Leptodactylus ocellatus $*$,\# & 103.00 & 356.00 \\
\hline Leptodactylus petersii & 37.50 & 308.00 \\
\hline Leptodactylus podicipinus & 36.40 & 576.00 \\
\hline Leptodactylus pustulatus & 38.00 & 60.00 \\
\hline Leptodactylus syphax & 73.70 & 98.00 \\
\hline Leptodactylus tapiti & 33.00 & 2.00 \\
\hline Leptodactylus troglodytes & 48.80 & 103.00 \\
\hline Lysapus limellus & 17.50 & 195.00 \\
\hline Odontophrynus americanus & 43.40 & 231.00 \\
\hline Odontophrynus cultripes $*$, \# & 57.00 & 150.00 \\
\hline Odontophrynus moratoi & 31.65 & 15.00 \\
\hline Odontophrynus salvatori* & 30.00 & 2.00 \\
\hline Phasmahyla jandai & 30.00 & 2.00 \\
\hline Phrynohyas venulosa & 61.00 & 492.00 \\
\hline Phyllomedusa burmeisteri & 110.20 & 39.00 \\
\hline Phyllomedusa centralis & 42.00 & 33.00 \\
\hline Phyllomedusa hypochondrialis*, \# & 31.50 & 454.00 \\
\hline Physalaemus albonotatus & 25.85 & 25.00 \\
\hline Physalaemus centralis* & 37.00 & 59.00 \\
\hline Physalaemus cuvieri*, \# & 28.50 & 326.00 \\
\hline Physalaemus deimaticus & 24.40 & 4.00 \\
\hline Physalaemus evangelistai & 21.50 & 18.00 \\
\hline Physalaemus fuscomaculatus & 45.00 & 228.00 \\
\hline Physalaemus nattereri* ${ }^{*}$ & 42.00 & 62.00 \\
\hline Proceratophrys cururu & 44.60 & 2.00 \\
\hline Proceratophrys goyana & 32.58 & 24.00 \\
\hline Pseudis bolbodactyla* & 35.00 & 367.00 \\
\hline Pseudopaludicola ameghini & 18.00 & 45.00 \\
\hline Pseudopaludicola falcipes & 15.80 & 1.00 \\
\hline Pseudopaludicola mineira & 14.30 & 2.00 \\
\hline Pseudopaludicola saltica & 18.14 & 32.00 \\
\hline Rana palmipes & 92.00 & 327.00 \\
\hline Scinax canastrensis & 31.98 & 4.00 \\
\hline Scinax centralis $*$ \# & 14.00 & 2.00 \\
\hline Scinax duartei & 26.50 & 2.00 \\
\hline Scinax fuscomarginatus*, \# & 24.00 & 158.00 \\
\hline Scinax machadoi & 23.50 & 5.00 \\
\hline Scinax maracaya & 26.86 & 1.00 \\
\hline Scinax nebulosus & 28.00 & 163.00 \\
\hline Scinax squalirostris & 25.00 & 331.00 \\
\hline Thoropa megatympanum & 42.00 & 47.00 \\
\hline
\end{tabular}

* Species found in the Silvânia region, Goiás.

\# Species found in the Silvânia region for which population dynamics data is available. 
Acknowledgments - We thank L.P. Lima and M.B. Alcantara for help in fieldwork, and Ibama for providing logistical support in Silvânia. Financial support was provided by several grants from CNPq (Programa Centro-Oeste de Pesquisa \& Pós-Graduação - PCOPG 520804/99-6, proc. 400381/97-4 to RPB, and productivity fellowships to JAFD-F, LMB, RPB and JPP-Jr), FUNAPE/UFG, and Capes.

\section{REFERENCES}

BINI, L. M., COELHO, A. S. \& DINIZ-FILHO, J. A. F., 2001, Is the relationship between population density and body size consistent across independent studies? A meta-analytical approach. Rev. Bras. Biol., 61: 1-6.

BLACKBURN, T. M. \& GASTON, K. J., 1994a, Animal body size distributions: patterns, mechanisms and implications. Trends Ecol. Evol., 9: 471-474.

BLACKBURN, T. M. \& GASTON, K. J., 1994b, The distribution of body sizes of the world's bird species. Oikos, 70: 127-130.

BLACKBURN, T. M. \& GASTON, K. J., 1997a, A critical assessment of the form of the interspecific relationship between abundance and body size in animals. J. Anim. Ecol., 66: 233-249.

BLACKBURN, T. M. \& GASTON, K. J., 1997b, The relationship between animal abundance and body size: a review of the mechanisms. Advances in Ecological Research, 28: 181-210.

BLACKBURN, T. M. \& GASTON, K. J., 1998, Some methodological issues in macroecology. Am. Nat., 151: 68-83.

BLACKBURN, T. M. \& GASTON, K. J., 2001, Linking patterns in macroecology. J. Animal Ecol., 70: 338-352.

BLAMIRES, D., DINIZ-FILHO, J. A. F., SANT'ANA, C. E. R. \& VALGAS, A. B., 2002, Relação entre abundância e tamanho do corpo em uma comunidade de aves no Brasil Central. Ararajuba, 10: 1-14.

BROWN, J. H. \& MAURER, B. A., 1987, Evolution of species assemblages: effects of energetic constraints and species dynamics on the diversification of North American avifauna. Am. Nat., 130: 1-17.

BROWN, J. H. \& MAURER, B. A., 1989, Macroecology: the division of food and space among species on continents. Science, 243: 1145-1150.

BROWN, J. H., 1995, Macroecology. University of Chicago Press, Chicago.

BROWN, J. H., 1999, Macroecology: progress and prospect. Oikos, 87: 3-14.

BROWN, J. H., MEHLMAN, D. W. \& STEVENS, G. C., 1995, Spatial variation in abundance. Ecology, 76: 2028-2043.

CARBONE, C. \& GITTLEMAN, J. L., 2002, A common rule for the scaling of carnivore density. Science, 295: 2273-2276.

CARDILLO, M., 2002, Body size and latitudinal gradients in regional diversity of New Word birds. Global Ecol. Biogeogr, 11: 59-65.

CHANNELL, R. \& LOMOLINO, M. V., 2000, Dynamic biogeography and conservation of endangered species. Nature, 403: 84-86.

COLLI, G. R., BASTOS, R. P. \& ARAÚJO, A. F. B., 2002, The character and dynamics of the Cerrado herpetofauna. In: P. S. Oliveira \& R. J. Marquis (eds.), The Cerrados of Brazil: ecology and natural history of a Neotropical savanna. Columbia University Press, Irvington, pp. 223-241.
CRUMP, M. L. \& SCOTT Jr., N. J., 1994, Visual encounter surveys. In: W. R. Heyer, M. A. Donnelly, R. W. McDiarmid, L. Hayek \& M. S. Foster (eds.), Measuring and monitoring biological diversity - standard methods for Amphibians. Smithsonian Inst. Press, Washington, pp. 84-91.

CYR, H., DOWNING, J. A. \& PETERS, R. H., 1997, Densitybody size relationships in local aquatic communities. Oikos, 79: 333-346.

DAMUTH, J., 1981, Population density and body size in mammals. Nature, 290: 699-700.

DUNCAN, R. P., BLACKBURN, T. M. \& VELTMAN, C. J., 1999, Determinants of geographical range sizes: a test using introduced New Zealand birds. J. Anim. Ecol., 68: 963-975.

GASTON, K. J., 1991, How large is a species geographic range. Oikos, 61: 434-438.

GASTON, K. J., 1994, Rarity. Chapman \& Hall, London.

GASTON, K. J. \& BLACKBURN, T. M., 1996, Range in sizebody size relationships: evidence of scale dependence. Oikos, 75: 479-485.

GASTON, K. J. \& BLACKBURN, T. M., 1999, A critique for macroecology. Oikos, 84: 353-368.

GASTON, K. J. \& BLACKBURN, T. M., 2000, Pattern and process in macroecology. Blackwell, London.

GOTELLI, N. J. \& ENTSMINGER, G. L., 2000, EcoSim: null models software for ecology (version 5.0). Acquired Intelligence Inc. \& Kesey-Bear.

LAWTON, J. H., 1989, What is the relationship between population density and body size in animals? Oikos, 55: 429-434.

LEVIN, S. A., 1992, The problem of pattern and scale in ecology. Ecology, 73: 1943-1967.

MAURER, B. A., 1994, Geographical population analysis. Blackwell Scientific Publications, Oxford.

MAURER, B., 1999, Untangling ecological complexity. University of Chicago Press, Chicago.

McARDLE, B. H., GASTON, K. J. \& LAWTON, J. H., 1990, Variation in the size of animal populations - patterns, problems and artifacts. J. Anim. Ecol., 59: 439-454.

MURRAY, B. R., FONSECA, C. \& WESTOBY, M., 1998, The macroecology of Australian frogs. J. Anim. Ecol., 67: 567579.

OLIVEIRA-FILHO, A. T. \& RATTER, J., 2002, The woody vegetation and the Cerrado Physionomies. In: P. S. Oliveira \& R. J. Marquis (eds.), The Cerrados of Brazil: ecology and natural history of a Neotropical savanna. Columbia University Press, Irvington, pp. 91-120.

RICKLEFS, R. E. \& SCHLUTER, D., 1993, Species diversity: regional and historical influences. In: R. E. Ricklefs \& D. Schluter (eds.), Species diversity in Ecological Communities. University of Chicago Press, Chicago, pp. 350-363.

SOKAL, R. R. \& ROHLF, F. J., 1995, Biometry. W. H. Freeman, New York.

ZIMMERMAN, B. L., 1994, Audio strip transects. In: W. R. Heyer, M. A. Donnelly, R. W. McDiarmid, L. Hayek \& M. $\mathrm{S}$. Foster (eds.), Measuring and monitoring biological diversity - standard methods for Amphibians. Smithsonian Inst. Press, Washington, pp. 92-96. 